\title{
Ankylosing spondylitis and trauma: the medicolegal implications. A comparative study of patients with non-specific back pain
}

\author{
R K JACOBY, ${ }^{1}$ R L M NEWELL, ${ }^{1}$ AND P HICKLING ${ }^{2}$ \\ From the ${ }^{1}$ Princess Elizabeth Orthopaedic Hospital, Exeter; and ${ }^{2}$ Mount Gould Hospital, Plymouth
}

SUMmARY Ankylosing spondylitis (AS) arising as a result of injury was reported by five of 113 hospital patients who completed questionnaires on the historical and symptomatic features of their disease. Identical questionnaires were given to a group of 51 patients with non-specific back pain (NSBP) attending an orthopaedic clinic. Five of these patients developed their first symptoms after trauma. A further four patients with ankylosing spondylitis believed that their disease was initiated by injury, however, $x$-ray photographs showed that they had already developed AS at the time of their injuries. It is suggested that injury does not cause AS but brings it to the patient's attention, possibly through immobilisation, in $7 \%$ of hospital cases.

Key words: injury, aetiology, compensation.

The relationship between the onset of an arthritis and a life event may be difficult to substantiate. However, meniscectomy appears to predispose to osteoarthritis and crystal deposition. ${ }^{1}$ Although injury to the joints can likewise lead to osteoarthritis, there is little evidence to suggest that inflammatory arthritis is triggered by trauma, with the possible exception of gout. ${ }^{2}$ After patients with ankylosing spondylitis (AS) whose disease became apparent following injury were seen, we retrospectively reviewed all our patients with AS to determine whether or not there had been any significant trauma before the disease became symptomatic.

For comparison we have taken a group of patients with non-specific back pain (NSBP) attending an orthopaedic clinic to establish whether any significant trauma had occurred at the onset of their symptoms. The symptomatic features of the backache were also sought in order to draw a distinction between the two groups of patients.

There has been no reported association between trauma and AS since some of the early descriptions of the disease,${ }^{34}$ and no prospective survey has been undertaken. In view of the prevalence of $\mathrm{AS}^{5}$ in the community it is inevitable that some subjects with

Accepted for publication 9 November 1984.

Correspondence to Dr R K Jacoby, Princess Elizabeth Orthopaedic Hospital, Wonford Road, Exeter EX2 4UE. this complaint will be involved in accidents. There is a need for some statement based on objective findings concerning the relationship between injury and the onset of AS. The patient's perception of the onset of his or her disease has important medicolegal implications which a lawyer would need to emphasise in his client's favour if injury had occurred shortly before the first symptoms of AS.

\section{Patients and methods}

One hundred and twenty-six consecutive patients fulfilling the New York criteria ${ }^{6}$ for AS were given or sent the questionnaire (Table 1); 113 patients $(90 \%)$ responded ( 77 men and 36 women, age $16-75$ years, mean 42.4 years). The NSBP patients were defined as those patients complaining of low back pain who had minimal signs and normal results of investigations, with the exception of spondylotic changes on radiology. The NSBP patients were all seen in one clinic where the questionnaires were filled out. The completion was $100 \%$ in 51 patients (27 men and 24 women, age $19-82$ years, mean 48.7 years). The reason for the study was not disclosed to the patients.

The information derived from the two groups of patients was compared statistically by the $\chi^{2}$ test, with Yates's correction for small samples. 


\section{Jacoby, Newell, Hickling}

Table 1 Back pain questionnaire

Name

Date of birth

How long have you had backache?

Pain brought on by:

Pain relieved by:

Frequency of episodes of backache:

Does exercise make your pain better or worse?

Does rest make your pain better or worse?

Have you sustained any injury to your back?

If yes describe the injury.

Did your injury start or alter your back pain?

Which area of your back has been painful? (indicate on the diagram)

Have you had any arthritis in your arms or legs?

If yes indicate which joints.

Have you had any inflammation of the eyes?

If yes what was it called by the doctor?

Have you ever had disease of the bowel called ulcerative colitis or Crohn's disease?

Have you ever had any skin disease?

If yes do you know what it is called?

Thank you for completing this questionnaire, which is part of a research project about back pain.

Table 2 Factors relieving the back pain

\begin{tabular}{|c|c|c|c|c|c|c|}
\hline \multirow[t]{2}{*}{ Response } & \multicolumn{2}{|c|}{$A S$ group } & \multicolumn{2}{|c|}{ NSBP group } & \multirow[t]{2}{*}{$x^{2}$} & \multirow[t]{2}{*}{$p$} \\
\hline & Number & $\%$ & Number & $\%$ & & \\
\hline Exercise & 49 & 43 & 2 & 4 & $23 \cdot 7$ & $<0.001$ \\
\hline NSAID or analgesia & 35 & 31 & 11 & 22 & $1 \cdot 11$ & \\
\hline Heat & 19 & 17 & 0 & 0 & $8 \cdot 12$ & $<0.001$ \\
\hline Nothing & 14 & 12 & 14 & 27 & 4.62 & $<0.05$ \\
\hline Lying flat & 3 & 3 & 0 & 0 & $0 \cdot 29$ & \\
\hline Rest & 10 & 9 & 26 & 51 & 33.98 & $<0.001$ \\
\hline Manipulation & $\mathbf{0}$ & 0 & 1 & 2 & $0 \cdot 16$ & NS \\
\hline Stretching spine & 0 & 0 & 1 & 2 & $0 \cdot 16$ & NS \\
\hline \multicolumn{7}{|c|}{$\begin{array}{l}\text { NSAID=non-steroidal anti-inflammatory drugs. } \\
\text { NS=not significant. }\end{array}$} \\
\hline \multicolumn{7}{|c|}{ Table 3 Duration of painful episodes } \\
\hline \multirow[t]{2}{*}{ Response* $^{*}$} & \multicolumn{2}{|c|}{$A S$ group } & \multicolumn{2}{|c|}{ NSBP group } & \multirow[t]{2}{*}{$x^{2}$} & \multirow[t]{2}{*}{$p$} \\
\hline & Number & $\%$ & Number & $\%$ & & \\
\hline Constant & 30 & 26 & 23 & 45 & $6 \cdot 53$ & $<0.02$ \\
\hline Lasting for weeks & 24 & 21 & 8 & 16 & $\mathbf{0 . 8 5}$ & NS \\
\hline Lasting for days & 51 & 45 & 7 & 14 & $13 \cdot 82$ & $<0.001$ \\
\hline Lasting for hours & 26 & 23 & 13 & 25 & $9.3 \times 10^{-3}$ & NS \\
\hline
\end{tabular}

*Eighteen AS patients gave two responses.

Table 4 Effect of exercise on back pain

\begin{tabular}{|c|c|c|c|c|c|c|}
\hline \multirow[t]{2}{*}{ Response } & \multicolumn{2}{|c|}{$A S$ group } & \multicolumn{2}{|c|}{ NSBP group } & \multirow[t]{2}{*}{$x^{2}$} & \multirow[t]{2}{*}{$p$} \\
\hline & Number & $\%$ & Number & $\%$ & & \\
\hline $\begin{array}{l}\text { Worse } \\
\text { Neither } \\
\text { Better }\end{array}$ & $\begin{array}{l}13 \\
15 \\
85\end{array}$ & $\begin{array}{l}12 \\
13 \\
75\end{array}$ & $\begin{array}{l}21 \\
15 \\
15\end{array}$ & $\begin{array}{l}41 \\
29 \\
29\end{array}$ & $\begin{array}{r}17.06 \\
5.09 \\
29.09\end{array}$ & $\begin{array}{l}<0.001 \\
\text { NS } \\
<0.001\end{array}$ \\
\hline
\end{tabular}


Table 5 Effect of rest on back pain

\begin{tabular}{|c|c|c|c|c|c|c|}
\hline \multirow[t]{2}{*}{ Response } & \multicolumn{2}{|l|}{$A S$ group } & \multicolumn{2}{|c|}{$N S B P$ group } & \multirow[t]{2}{*}{$x^{2}$} & \multirow[t]{2}{*}{$p$} \\
\hline & Number & $\%$ & Number & $\%$ & & \\
\hline Worse & 56 & 50 & 6 & 12 & $19 \cdot 76$ & $<0.001$ \\
\hline Neither & 8 & 7 & 12 & 24 & $7 \cdot 41$ & $<0.01$ \\
\hline Better & 49 & 43 & 33 & 65 & $6 \cdot 23$ & $<0.01$ \\
\hline
\end{tabular}

Table 6 The relationship between injury and AS or NSBP

\begin{tabular}{|c|c|c|c|c|c|c|c|}
\hline$A S$ group & Injury & Number & $N S B P$ group & Injury & Number & $x^{2}$ & Significance \\
\hline $\begin{array}{l}\text { Symptoms began after the } \\
\text { accident, within days. } \\
\text { No evidence of disease } \\
\text { beforehand }\end{array}$ & Major & 5 & $\begin{array}{l}\text { Symptoms started within } \\
\text { days of the accident }\end{array}$ & Major & 5 & 0.96 & NS \\
\hline $\begin{array}{l}\text { Disease brought to light after } \\
\text { trauma. } X \text {-ray changes } \\
\text { already present but no } \\
\text { symptoms up to then }\end{array}$ & $\begin{array}{l}\text { Major } \\
\text { Minor }\end{array}$ & 3 & & & & & \\
\hline $\begin{array}{l}\text { Disease already diagnosed, } \\
\text { but the patient experienced } \\
\text { a flare up of symptoms } \\
\text { lasting less than two months }\end{array}$ & $\begin{array}{l}\text { Major } \\
\text { Minor }\end{array}$ & 1 & $\begin{array}{l}\text { Symptoms already present } \\
\text { but were aggravated for } \\
\text { less than two months }\end{array}$ & $\begin{array}{l}\text { Major } \\
\text { Minor }\end{array}$ & 2 & $\begin{array}{l}0.51 \\
2.8 \times 10^{-3}\end{array}$ & NS \\
\hline $\begin{array}{l}\text { Disease already established, } \\
\text { but injury had no effect on } \\
\text { the disease }\end{array}$ & $\begin{array}{l}\text { Major } \\
\text { Minor }\end{array}$ & 3 & $\begin{array}{l}\text { Symptoms already established, } \\
\text { but injury had no effect on } \\
\text { them }\end{array}$ & $\begin{array}{l}\text { Major } \\
\text { Minor }\end{array}$ & $\begin{array}{l}4 \\
1\end{array}$ & $\begin{array}{l}1.22 \\
3.5 \times 10^{-2}\end{array}$ & $\begin{array}{l}\text { NS } \\
\text { NS }\end{array}$ \\
\hline
\end{tabular}

\section{Results}

The responses to some of the questions outlined in Table 1 are given in Tables 2-6. Table 6 describes the time relationship between trauma and the AS or NSBP. Forty-eight of the AS patients had peripheral joint involvement, of whom four had inflammatory bowel disease (IBD). There were no other cases of IBD in the whole sample. Five AS patients had psoriasis and 31 experienced iritis or conjunctivitis, or both.

\section{Discussion}

Few data have been published on the association between any of the spondylarthropathies ${ }^{7}$ and trauma. Three patients described in $1967,,^{8}$ one of whom was thought to have psoriasis, appeared to develop chronic inflammatory polyarthritis after injury to the hands. Experimental traumatic arthritis in animals ${ }^{9}$ has not been shown to initiate chronic inflammatory arthritis. However, the intra-articular injection of fibrin into previously sensitised rabbits ${ }^{10}$ will do so. It is possible that some endogenous agent such as fibrin could be released at the site of injury, giving rise to a chronic inflammatory process.

Although it is now known that people who carry the tissue antigen HLA-B27 are about 76 times more likely to get AS than people who are B27 negative ${ }^{11}$ it is not possible to predict who will actually develop AS. It has recently been shown that $21 \%$ of HLA-B27 positive relatives of patients with AS have also developed the disease by the age of $45 .^{12}$ It would therefore be necessary to screen prospectively the B27 positive siblings and children of AS sufferers for both trauma and symptoms over several decades to see whether trauma could initiate AS. Furthermore the screening would need to be done at frequent intervals so that no injury however trivial would go unrecorded. It therefore seemed to us to be impractical to study this problem in a prospective way.

In a study of the earliest stages of AS one is limited to the symptoms reported by the patient, which would be expected to develop before any radiological change. However, in four of the patients described in Table 6 radiological changes occurred first. One can only conclude from this evidence that symptoms do not necessarily indicate the beginning of AS, but there are no satisfactory alternative parameters to study.

In view of the difficulty in choosing a control group it was decided to compare the AS patients with patients attending an orthopaedic clinic suffer- 
ing from NSBP. As it is thought that NSBP is mechanical in nature, one might expect to bias the study against the AS group. However, the difference in the two groups between the number of injuries sustained just before the first symptoms is not significant. It is possible that the sex difference of the two groups could account for this. Even if more of the AS patients had been injured just before their first symptoms, this would not have been conclusive evidence of an aetiological role, as the groups of patients are not matched. However, it is felt that the comparison is a meaningful one despite these drawbacks. AS spans many years of a patient's life and it is quite possible for sufferers to experience non-spondylitic back pain. It was therefore important to distinguish between the two groups in this survey. Clinical history has been shown to be a useful method of identifying AS within the spectrum of back pain, ${ }^{13}$ and in this survey the two groups differed significantly $(p<0.001)$ in their response to questions on rest and exercise. The questionnaires also reveal that a quarter of AS subjects experience perpetual symptoms, which contrasts with the relapsing nature of the disease described by Wilkinson and Bywaters. ${ }^{14}$ The other points covered by the questionnaires reveal considerable overlap in the clinical symptoms of AS and NSBP, which suggests that some of the pain in both conditions has a common origin.

This survey has shown that there was no significant difference between the number of injuries sustained in either group of patients at the time of onset of their symptoms. Furthermore there is no evidence to suggest that trauma is an important cause of AS. It could be argued that any group of people sustain injuries from time to time, and that AS sufferers do so as much as people with NSBP. The onset of AS may well be silent, as suggested by the four patients who already had radiological changes but had not experienced any back pain until they were injured. Is it in fact the case that injury brings subclinical AS to the patients attention? The five patients with AS who noticed their first symptoms after injury to the back were all treated with rest. As rest has been shown to aggravate the symptoms of AS, we suggest that unaccustomed immobilisation produced the symptoms and therefore brought the disease to the patient's attention. Our figures suggest that at least nine of the 113 patients in our sample $(8 \%)$ had insidious AS, whose symptoms were only revealed after injury. The analysis in Table 6 also suggests that in common with NSBP an exacerbation of AS can be precipitated by trauma. However, it is possible to sustain an injury to the back without exacerbation of disease. Exacerbations of AS need to be dis- tinguished from traumatic lesions which have beenọ reported to occur in rigid spines and resolve within two weeks. ${ }^{15}$ There are no absolutely reliable objective ways of detecting disease activity in AS.

The legal requirements to prove an association between injury and arthritis have been considered $\frac{}{5}$ by the Swiss National Accident Fund. ${ }^{16}$ The fore- $\frac{\mathbb{Q}}{\Omega}$ most fact is that the absence of incapacity before ano injury is not proof that a joint was previously intact. Furthermore only those joints directly injured ${ }_{-}^{\circ}$ should be considered as suffering from post-trauma- $\vec{\omega}$ tic arthritis. Spinal arthritis has been considered $\odot$ specifically by the Ontario Workman's Compensation Board, ${ }^{17}$ which finds no proof that MarieStrümpell disease (AS) is speeded up by trauma. Since it is not possible to design any investigation tow compare injured and uninjured patients with AS, the influence of trauma on established disease응 cannot be studied in a controlled fashion. The effect of injury in triggering the disease is likewise 3 unproved, but unquestionably a small number of patients do notice their first symptoms during the $\vec{\bullet}$ period following an injury. As it is felt that enforced immobilisation is possibly the reason for the appearance of symptoms which might otherwise not have occurred, there should be room for some legal compensation in these cases. One must accept that radiological evidence of the disease may not have $\frac{0}{\mathbb{D}}$ developed at the time of the injury. Our methods of $\varrho$ early diagnosis are poor.

\section{References}

1 Doherty M, Watt I, Dieppe P A. Localised chondrocalcinosis in postmeniscectomy knees. Lancet 1982; i: 1207-9.

2 Smyth C J. Diagnosis and treatment of gout. In: Hollander J L.O McCarthy D J, eds. Arthritis. Philadelphia: Lea and Febiger 1972.

3 Bechterew W von. Steifigkeit der Wirbelsäule und ihre Verkrümmung als besondere Erkankungsform. Neurol Zen tralbl 1983; 12: 426-34.

4 Wehrsig. Zur Kenntnis der chronischen Wirbelsäulenversteifung. Virchows Arch (Pathol Anat) 1910; 202: 305-18.

5 Calin A, Fries J F. Striking prevalence of ankylosing spondylitis in 'healthy' W27 positive males and females: a controlled study N $N$ Engl J Med 1975; 293: 835-9.

6 Bennet P H, Burch T A. Population studies of the rheumatid diseases. Amsterdam: Excerpta Medica. 1968.

7 Moll J M H, Haslock I, MacRae I F, Wright V. Association W

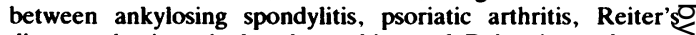
disease, the intestinal arthropathies and Behçet's syndrome Medicine (Baltimore) 1974; 53: 343.

8 Williams $K A$, Scott $J$ T. Influence of trauma on the development of chronic inflammatory polyarthritis. Ann Rheum Dis 1967; 26: 532-7.

9 Gardner D L. The experimental production of arthritis, a review. Ann Rheum Dis 1960; 19: 297-317.

10 Dumonde D C, Glynn L E. The production of arthritis in rabbits by an immunological reaction to fibrin. Br J Exp Pathob 1962; 43: 373-88.

11 Woodrow J C. Histocompatibility antigens and the rheumatic diseases. Semin Arthritis Rheum 1977; 6: 257. 
12 Linden S M van der, Valkenburg H A, Jongh B M, Cats A. The risk of developing ankylosing spondylitis in HLA B27 positive individuals. Arthritis Rheum 1984; 27: 241-9.

13 Calin A, Porta J, Fries J F, Shurman D J. Clinical history as a screening test for ankylosing spondylitis. JAMA 1977; 237: 2613-4.

14 Wilkinson M, Bywaters E G L. Clinical features and course of ankylosing spondylitis as seen in a follow up of 222 hospital referred cases. Ann Rheum Dis 1958; 17: 209-25.

15 Hart F D. In: Moll J M H, ed. Ankylosing spondylitis. Edinburgh: Churchill Livingstone, 1980.

16 Marmor D. The arthritides; special note on trauma. Med Trial Tech $Q$ 1969; 16: 61-8.

17 Willis T A. The medical-legal relation to spinal arthritis. Ohio State Med J 1958; 54: 1052-81. 